\title{
Clinicopathological Significances of EZH2 \& Twist-1 Combined Expressions in Renal Cell Carcinoma (RCC)
}

\author{
ABLA S. MAHMOUD, M.D. and DINA A. KHAIRY, M.D. \\ The Department of Pathology, Faculty of Medicine, Beni-Suef University, Beni-Suef, Egypt
}

\begin{abstract}
Background: Renal cell carcinoma (RCC) is considered the commonest and most fatal malignant neoplasm of the kidney. Distant metastases are found in 30\% of RCC patients at diagnosis, which is considered an important sign of prediction of patients' prognosis. So trying to clarify molecular mechanisms of metastases in RCC could help to discover a recent therapeutic target to decrease and control distant metastases and subsequently might improve patients prognosis.
\end{abstract}

Aim of the Study: Was to assess the EZH2 \& Twist-1 combined expressions in RCC tissues with different histopathological subtypes and to correlate their expression with clinicopathological parameters.

Material and Methods: We have assessed expression of EZH2 \& Twist-1 in tissue by using immunohistochemistry in 50 paraffin blocks of RCC different histopathological subtypes, analyzed correlations between the levels of combined expressions and clinicopthological data.

Results: Increased EZH2 expression was positively associated with advanced AJCC stage, Lymph Node (L.N) metastases $(p=0.006)$, higher grade $(p<0.001)$, and presence of distant metastases $(p=0.045)$. Increased Twist- 1 expression was positively associated with higher grade, L.N $(p<0.001)$ $\&$ distant metastases $(p=0.04)$ and AJCC stage $(p=0.01)$. Both EZH\& Twist-1 expressions were positively correlated to each other $(p<0.001)$

Conclusion: EZH2 \& Twist-1 are considered markers of poor prognosis in RCC and so they could be used as novel therapeutic targets in $\mathrm{RCC}$ patients.

Key Words: Renal cell carcinoma (RCC) - EZH2 - Twist-1 Immunohistochemistry - Distant metastases.

\section{Introduction}

RENAL cell carcinoma (RCC) is considered the commonest and most fatal malignant neoplasm of the kidney; globally [1] . Although many RCC patients are diagnosed at early stages, but $30 \%$ of

Correspondence to: Dr. Abla S. Mahmoud,

The Department of Pathology, Faculty of Medicine,

Beni-Suef University, Beni-Suef, Egypt patients will have subsequently metastatic and incurable disease [2]. Discovering recent biomarkers is needed to decrease and control distant metastases and subsequently might improve patients prognosis. Usually cancer size, grade and stage could predict patients' outcome [3], but it was stated that patients with RCC having the same pathological stage might have variable outcomes that need further clarification. Enhancer, of, zeste, homolog, 2 (EZH-2) is a histone methyl transferase that can silence plethora of variable tumor suppressor genes and was found to be mapped on chromosome 7q35 , is a member of the poly, comb, group genes family that function to allow the transmission of genes expression patterns to the daughter cells with a stability. EZH2 have vital roles in RCCcarcinogenesis [4]. Although it's exact role of action is still unproved.

The process in which cells could change their phenotype from the epithelial to the mesenchymal states is called the epithelial-mesenchymal transition (EMT). EMT leads to many changes in the differentiated characteristics of the cells e.g. Adhesion and apical basal polarity between cells, additionally, leads to change in the absence of mobility and acquire instead mesenchymal characters e.g. invasiveness motility, and resistance to apoptosis and by such process malignant cells could acquire invasive and metastatic capability [5]. EMT is regulated by plethora of transcription factors like Twist-1 that is a basic helix-loop-helix (bHLH) transcription factor which is characterized by a DNA binding site which could that target the consensus E-box sequence 59-CANNTG-39 and another helix-loop-helix site [6]

The aim was to assess the EZH2 \& Twist-1 combined expressions in RCC tissues with different 
histopathological subtypes and to correlate their expression with clinicopathological parameters.

\section{Material and Methods}

This is a retrospective cohort study where we have included 50 archival formalin-fixed, paraffin blocks of RCC with different histopathological subtypes that were processed and diagnosed in Pathology Department, Faculty of Medicine, BeniSuef University and Cairo University Hospital, in the period from 2014 up to 2016. We recorded the detailed clinic-pathologic data for all cases. We used the T-N-M classification for pathologic-RCCstaging and The WHO 2016 classification of malignancies of the Urinary System for grading $[7,8]$ Our study followed Local-Ethics-Committeeguidelines.

\section{Immunohistochemical staining:}

Streptavidine-biotin technique was used for assessment of the immunohistochemical staining [9], we have incubated sections from all paraffin blocks with primary monoclonal mouse anti-EZH2 antibody (MA, Danvers, USA Cell Signaling Technology) (dilution at 1:100) and primary polyclonal rabbit anti-Twist antibody (Abcam, Cambridge, UK ab50581) (dilution at 1:50). We have used carcinomas of the breast and thyroid sections as positive controls for EZH2 and Twist-1 respectively and we have omitted the primary antibodies for negative controls then we had replaced them with phosphate-buffered saline.

Assessment of EZH-2- \& Twist-1 immunohistochemical-expressions:

We have evaluated nuclear stain intensity for both markers and graded it as 0 ; negative, 1 ; weak, 2 ; moderate $\& 3$ as strong intensity, while we have assessed the nuclear stain extent for both markers as 1 calculated from 0 to $25 \%, 2$ calculated from $26-50 \%, 3$ calculated from $51-75 \%$, and 4 calculated from 76-100\%. Finally we have multiplied both extent and intensity of each marker expression to reach final staining scores from 0-12 [10], we have used 4 as a final cut-off score and we considered scores fewer than 4 as decreased expressions and a scores equal to or greater than 4 as increased expression.

\section{Statistical-analysis:}

We have used the SPSS 22.0 program for windows (SPSS Inc., USA Chicago) and MedCalc (MedCalc, Software 13, Belgium) in statistical assessments. We evaluated continuous variables by the mean \pm SD \& median (range), \& categorical variables were evaluated by number (percentage), we used Mann-Whitney-U test to compare between non-normally distributed variables, also we have used Kraskall-Wallis-H test for comparison between more than 2 non-normally distributed groups of variables, finally we have used Fisher's-exact test or Pearson's Chi-square-test for comparison between categorical variables. $p$-value $<0.05$ was considered significant.

\section{Results}

\section{Demographic data:} (1).

The demographic data are summarized in Table

We have included 50 RCC patients that are diagnosed as $40(80 \%)$ cases with clear cell renal cell carcinoma (cc-RCC), 6 (12\%) papillary renal cell carcinoma (p-RCC) and 4 (8\%) chromophope renal cell carcinoma (cp-RCC) with their ages ranged from (40-77) years. 40 (80\%) patients were males and $10(20 \%)$ were females.

\section{Immunohistochemical results:}

EZH2 expression:

EZH2 increased expression was detected in 28 out of $50(56 \%)$ cases of RCC and was significantly positively correlated with higher grade of the tumor $(p<0.001)$, higher T stage of the tumor $(p=0.009)$, presence of distant metastases $(p=0.045)$, presence of L.N metastases and advanced AJCC stage $(p=0.006)$.

There were no significant correlations were found with age or sex of the patient, histopathological subtypes or size of the tumor (Figs. 1,2 \& Tables 2,4).

\section{Twist-1 expression:}

- Twist-1 increased expression was detected in 30 out of $50(60 \%)$ cases of RCC and was and was significantly positively correlated with higher grade of the tumor, higher $\mathrm{T}$ stage of the tumor $(p<0.001)$, presence of distant metastases $(p=0.04)$, presence of L.N metastases and advanced AJCC stage $(p=0.008)$,

- There were no significant correlations were found with age or sex of the patient, histopathological subtypes or size of the tumor (Fig. $3 \&$ Tables $3,4)$.

- We found a significant positive association between both markers expression $(p<0.001)$.

- Combination of EZH-2 \& Twist overexpression was significantly positively correlated with grade, stage of the tumor, presence of L.Ns and D.M $(p<0.001$ for all) (Table 4). 


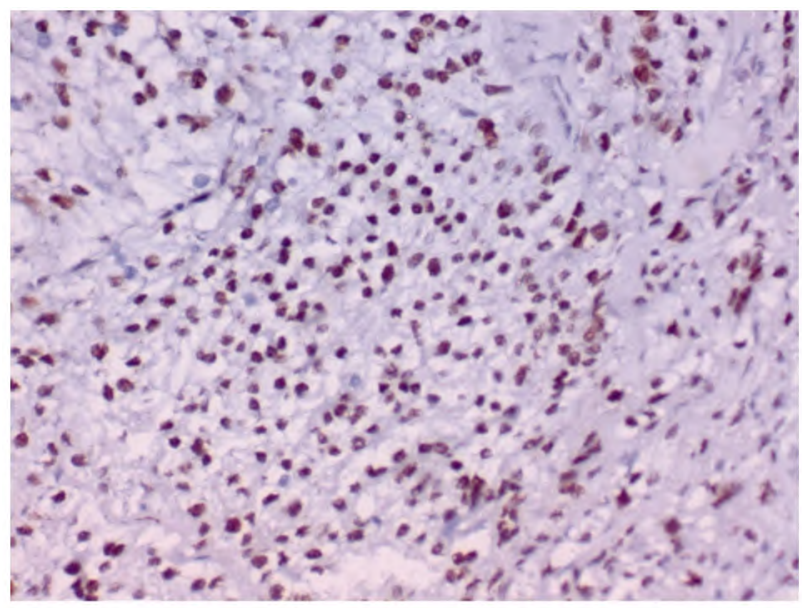

(A)
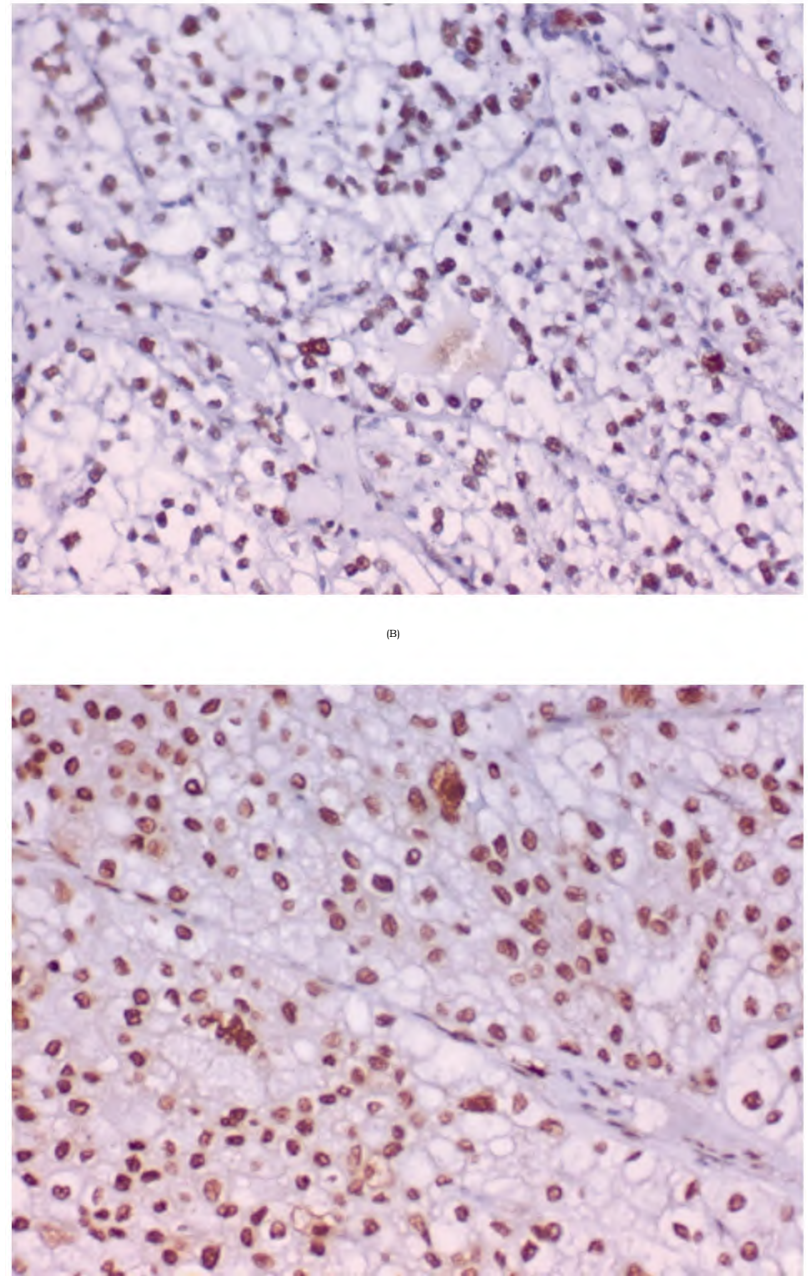

(C)

Fig. (1): Immunohistochemical expression of EZH2 in renal cell carcinoma (RCC): (A) High expression in nucleus of clear cell RCC grade III stage IVx400 (B) High expression in nucleus of clear cell RCC grade II stage IIIx400 (C) High expression in nucleus of chromophope RCC grade II stage III x400. Note: High EZH2 immunohistochemical expression in high grade \& stage RCC.

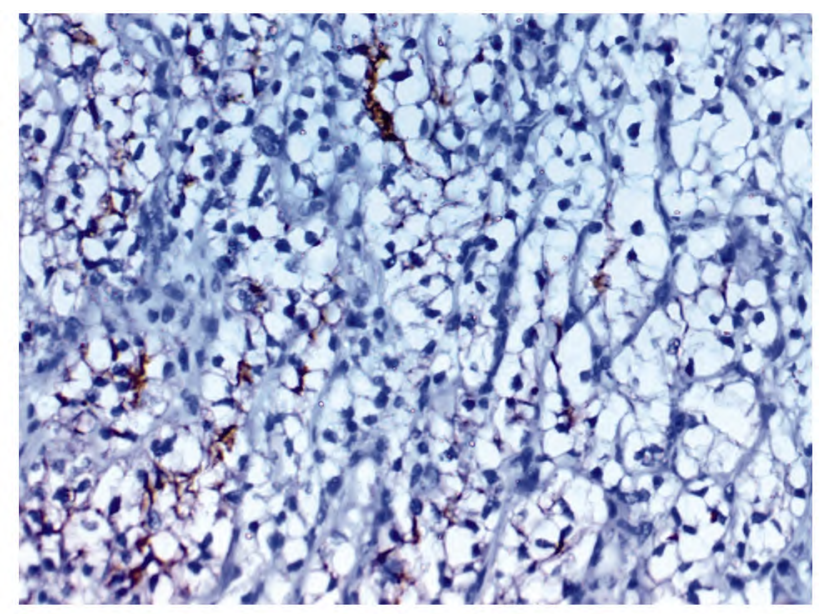

(A)

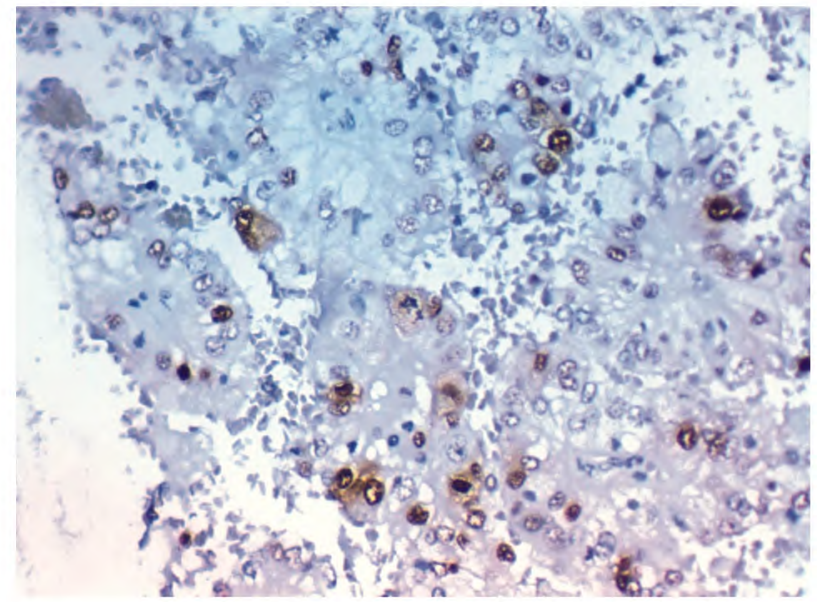

(B)

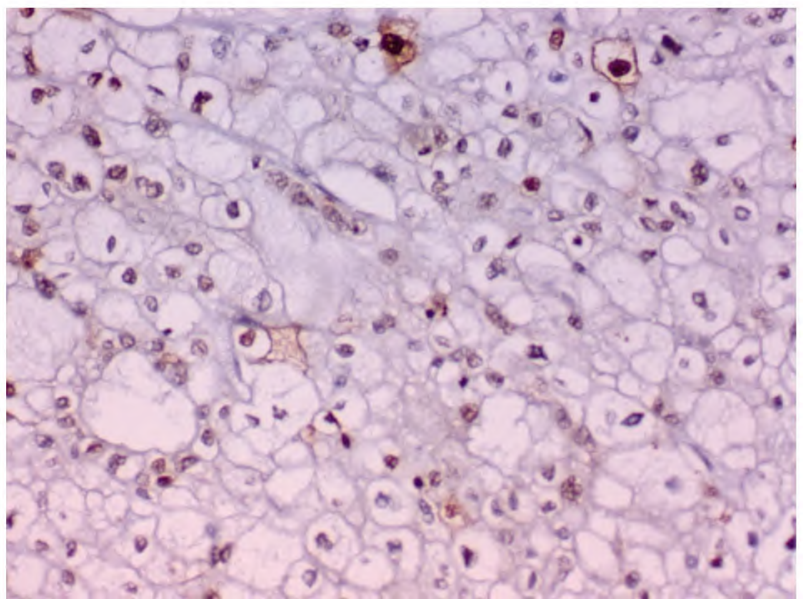

(C)

Fig. (2): Immunohistochemical expression of EZH2 in renal cell carcinoma (RCC): (A) Low expression in nucleus of clear cell RCC grade I stage Ix400 (B) Low expression in nucleus of papillary RCC grade I stage IIx400. (C) Low expression in nucleus of chromophope RCC grade I stage Ix400. Note: Low EZH2 immunohistochemical expression in Low grade \& stage RCC. 

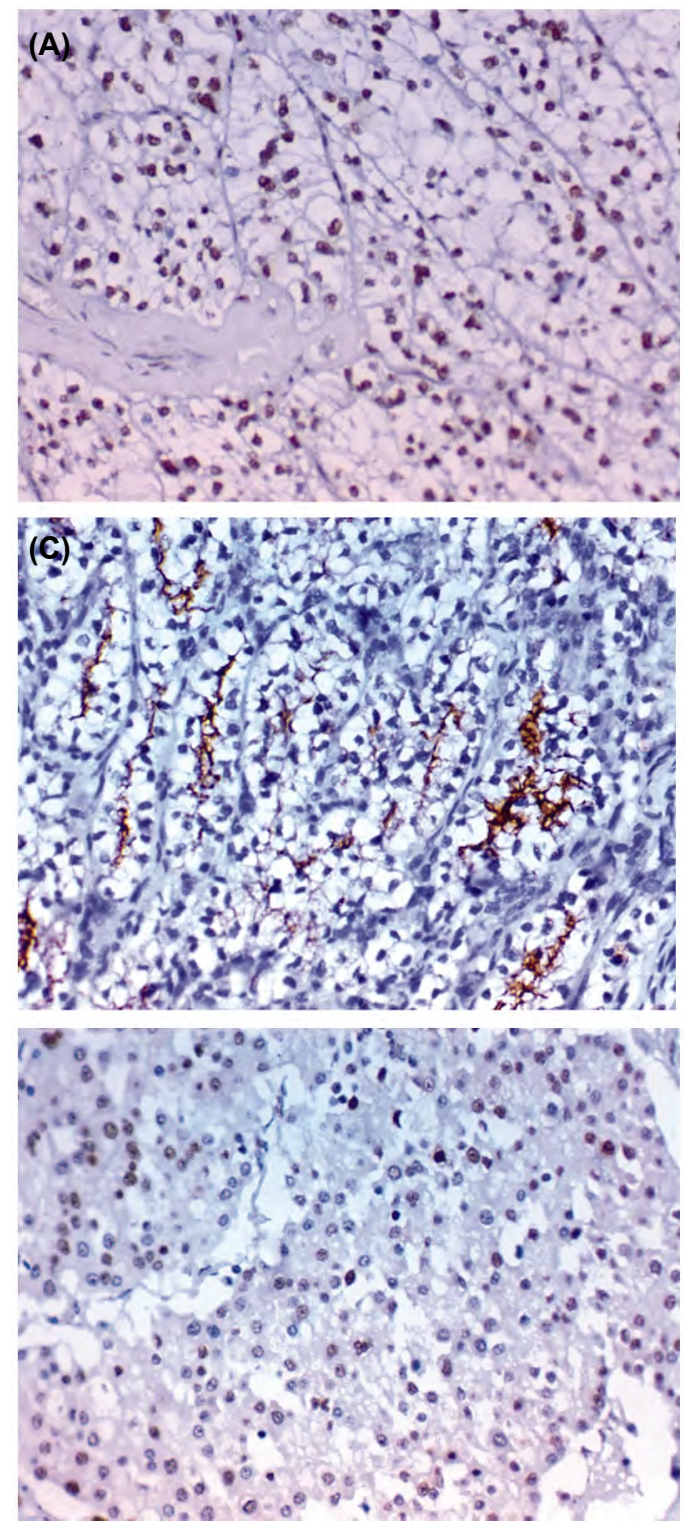

Table (1): Clinicopathological data, EZH2 \& Twist-1 expressions in our cases.

\begin{tabular}{|c|c|c|c|c|}
\hline \multicolumn{2}{|l|}{ Characteristics } & \multicolumn{2}{|l|}{ No. } & $\%$ \\
\hline Age years: & $\begin{array}{l}\text { Mean } \pm \text { SD } \\
\text { Median (Range) } \\
\leq 55 \text { years } \\
>55 \text { years }\end{array}$ & $\begin{array}{l}20 \\
30\end{array}$ & $\begin{array}{l}59.65 \pm 10.12 \\
64(40-77)\end{array}$ & $\begin{array}{l}40 \\
60\end{array}$ \\
\hline Sex: & $\begin{array}{l}\text { Male } \\
\text { Female }\end{array}$ & $\begin{array}{l}40 \\
10\end{array}$ & & $\begin{array}{l}80 \\
20\end{array}$ \\
\hline Pathological type: & $\begin{array}{l}\text { Clear cell } \\
\text { Papillary } \\
\text { Chromphobe }\end{array}$ & $\begin{array}{l}40 \\
6 \\
4\end{array}$ & & $\begin{array}{l}80 \\
12 \\
8\end{array}$ \\
\hline Grade: & $\begin{array}{l}\text { Grade I } \\
\text { Grade II } \\
\text { Grade III } \\
\text { Grade IV }\end{array}$ & $\begin{array}{l}8 \\
18 \\
12 \\
12\end{array}$ & & $\begin{array}{l}16 \\
36 \\
24 \\
24\end{array}$ \\
\hline Size: & $\begin{array}{l}<7 \mathrm{~cm} \\
>7 \mathrm{~cm}\end{array}$ & $\begin{array}{l}10 \\
40\end{array}$ & & $\begin{array}{l}20 \\
80\end{array}$ \\
\hline$T:$ & $\begin{array}{l}\text { T1 } \\
\text { T2 } \\
\text { T3 } \\
\text { T4 }\end{array}$ & $\begin{array}{l}10 \\
20 \\
10 \\
10\end{array}$ & & $\begin{array}{l}20 \\
40 \\
20 \\
20\end{array}$ \\
\hline
\end{tabular}
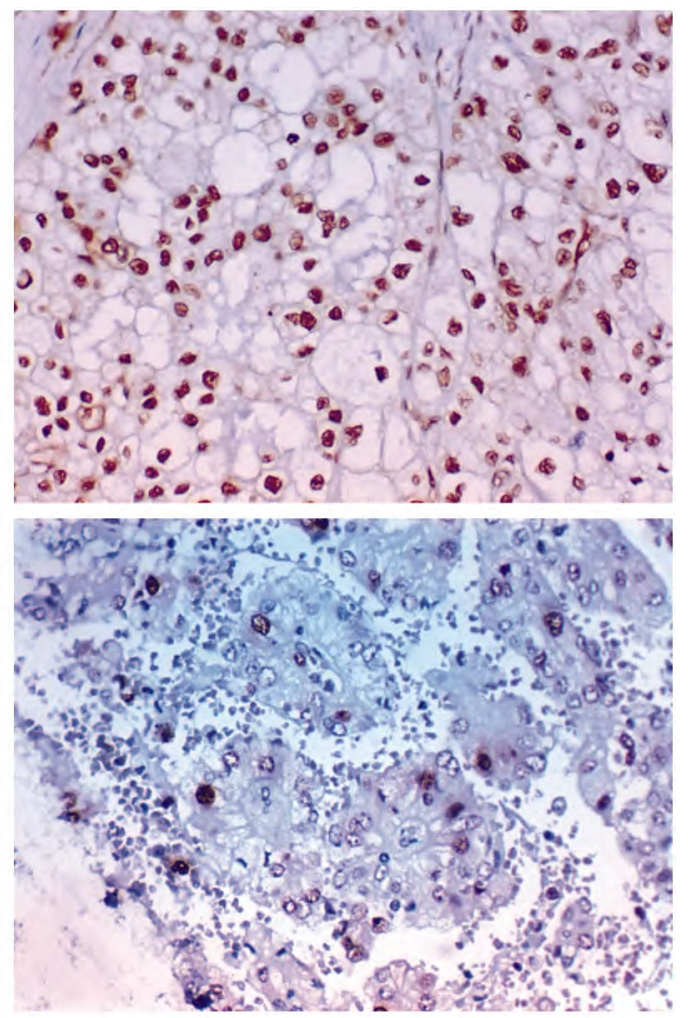

-1 in

leus

sion

ote:

rade

cell

is of

$\mathrm{n}$ in

ote:

rade
Table (1): Cont.

\begin{tabular}{llll}
\hline Characteristics & & No. & $\%$ \\
\hline$T: N:$ & N0 & 30 & 60 \\
& N1 & 20 & 40 \\
M: & M0 & 40 & 80 \\
& M1 & 10 & 20 \\
AJCC Stage group: & Stage I & 10 & 20 \\
& Stage II & 20 & 40 \\
& Stage III & 10 & 20 \\
& Stage IV & 10 & 20 \\
EZH2: & Low & 22 & 50 \\
& High & 28 & 50 \\
Twist-1: & Low & 20 & 40 \\
& High & 30 & 60 \\
EZH2/Twist-1 & Low/Low & 20 & 40 \\
& Low/High & 5 & 10 \\
& High/Low & 5 & 10 \\
& High/High & 20 & 40 \\
\hline
\end{tabular}


Table (2): Correlations between clinicopathological features and EZH2 expressions in our patients.

\begin{tabular}{|c|c|c|c|c|c|c|c|}
\hline \multirow{3}{*}{ Characteristics } & & & \multicolumn{4}{|c|}{$\mathrm{EZH} 2$} & \multirow{3}{*}{$p$-value } \\
\hline & \multicolumn{2}{|c|}{ All $(\mathrm{N}=50)$} & \multicolumn{2}{|c|}{ Low (N=22) } & \multicolumn{2}{|c|}{ High $(\mathrm{N}=28)$} & \\
\hline & No. & $\%$ & No. & $\%$ & No. & $\%$ & \\
\hline \multicolumn{8}{|l|}{ Age (years): } \\
\hline Mean \pm SD & \multicolumn{2}{|c|}{$59.65 \pm 10.12$} & \multicolumn{2}{|c|}{$557.57 \pm 10.01$} & \multicolumn{2}{|c|}{$61.73 \pm 9.97$} & \multirow[t]{2}{*}{$0.037 \bullet$} \\
\hline Median (Range) & \multicolumn{2}{|c|}{$64(40-77)$} & \multicolumn{2}{|c|}{$62.50(40-77)$} & \multicolumn{2}{|c|}{$65.50(40-75)$} & \\
\hline 55 years & 20 & 40 & 12 & $(58.3)$ & 8 & $(41.7)$ & \multirow[t]{2}{*}{$0.292 \ddagger$} \\
\hline$>55$ years & 30 & 60 & 10 & $(44.4)$ & 20 & $(55.6)$ & \\
\hline \multicolumn{8}{|l|}{ Sex: } \\
\hline Male & 40 & 80 & 20 & $(50)$ & 20 & $(50)$ & \multirow{2}{*}{$1.000 \ddagger$} \\
\hline Female & 10 & 20 & 2 & $(50)$ & 8 & $(50)$ & \\
\hline \multicolumn{8}{|l|}{ Pathological type: } \\
\hline Clear cell & 40 & 80 & 18 & $(46.6)$ & 22 & $(53.4)$ & \multirow{3}{*}{$0.368 \ddagger$} \\
\hline Papillary & 6 & 12 & 2 & $(55.6)$ & 4 & (44.4) & \\
\hline Chromphobe & 4 & 8 & 2 & $(20)$ & 2 & $(80)$ & \\
\hline \multicolumn{8}{|l|}{ Grade: } \\
\hline Grade I & 8 & 16 & 7 & $(93.3)$ & 1 & (6.7) & \multirow{4}{*}{$<0.001 \S$} \\
\hline Grade II & 18 & 36 & 9 & $(50)$ & 9 & $(50)$ & \\
\hline Grade III & 12 & 24 & 3 & $(23.5)$ & 9 & $(76.5)$ & \\
\hline Grade вг & 12 & 24 & 3 & $(16.7)$ & 9 & $(83.3)$ & \\
\hline \multicolumn{8}{|l|}{ Size: } \\
\hline$<7 \mathrm{~cm}$ & 10 & 20 & 4 & $(58.8)$ & 6 & $(41.2)$ & \multirow{2}{*}{$0.390 \ddagger$} \\
\hline$>7 \mathrm{~cm}$ & 40 & 80 & 18 & $(46.5)$ & 22 & $(53.5)$ & \\
\hline$T:$ & & & & & & & \\
\hline $\mathrm{T} 1$ & 10 & 20 & 7 & $(66.7)$ & 3 & (33.3) & \\
\hline $\mathrm{T} 2$ & 20 & 40 & 12 & $(66.7)$ & 8 & $(33.3)$ & $0.009 \S$ \\
\hline $\mathrm{T} 3$ & 10 & 20 & 3 & $(35.3)$ & 7 & $(64.7)$ & \\
\hline $\mathrm{T} 4$ & 10 & 20 & 0 & $(0)$ & 10 & (100) & \\
\hline$N:$ & & & & & & & \\
\hline N0 & 30 & 60 & 20 & $(67.6)$ & 10 & $(32.4)$ & \\
\hline N1 & 20 & 40 & 8 & $(26.9)$ & 12 & $(73.1)$ & $0.006 \ddagger$ \\
\hline M: & & & & & & & \\
\hline M0 & 40 & 80 & 19 & $(55.1)$ & 21 & $(44.9)$ & $0045+$ \\
\hline M1 & 10 & 20 & 3 & $(27.3)$ & 7 & $(72.7)$ & $0.045 \%$ \\
\hline AJCC Stage group: & & & & & & & \\
\hline Stage I & 10 & 20 & 7 & $(66.7)$ & 3 & (33.3) & $0.006 \S$ \\
\hline Stage II & 20 & 40 & 12 & $(68.4)$ & 8 & (31.6) & .0008 \\
\hline Stage III & 10 & 20 & 2 & $(33.3)$ & 8 & $(66.7)$ & \\
\hline Stage IV & 10 & 20 & 1 & $(21.4)$ & 9 & (78.6) & \\
\hline EZH2: & & & & & & & \\
\hline Negative & 22 & 40 & & & & & \\
\hline Positive & 28 & 60 & & & & & \\
\hline Twist-1: & & & & & & & \\
\hline Low & 20 & 80 & 18 & $(89.7)$ & 2 & (10.3) & \\
\hline High & 30 & 20 & 4 & $(12.9)$ & 26 & $(87.1)$ & $<0.001 \%$ \\
\hline
\end{tabular}

* Mann Whitney U test. 
Table (3): Correlations between clinicopathological features and Twist-1 expressions in our patients.

\begin{tabular}{|c|c|c|c|c|c|c|c|}
\hline \multirow{3}{*}{ Characteristics } & & & \multicolumn{4}{|c|}{ Twist-1 } & \multirow{3}{*}{$p$-value } \\
\hline & \multicolumn{2}{|c|}{ All $(\mathrm{N}=50)$} & \multicolumn{2}{|c|}{ Low $(\mathrm{N}=20)$} & \multicolumn{2}{|c|}{ High $(\mathrm{N}=30)$} & \\
\hline & No. & $\%$ & No. & $\%$ & No. & $\%$ & \\
\hline \multicolumn{8}{|l|}{ Age (years): } \\
\hline Mean \pm SD & \multicolumn{2}{|c|}{$59.65 \pm 10.12$} & \multicolumn{2}{|c|}{$57.76 \pm 10.18$} & \multicolumn{2}{|c|}{$61.42 \pm 9.91$} & \multirow[t]{2}{*}{$0.083 *$} \\
\hline Median (Range) & \multicolumn{2}{|c|}{$64(40-77)$} & \multicolumn{2}{|c|}{$63(40-77)$} & \multicolumn{2}{|c|}{$65(40-75)$} & \\
\hline$\leq 55$ years & 20 & 40 & 10 & $(50)$ & 10 & $(50)$ & \multirow[t]{2}{*}{$0.460 \ddagger$} \\
\hline$>55$ years & 30 & 60 & 10 & $(44.4)$ & 20 & $(55.6)$ & \\
\hline \multicolumn{8}{|l|}{ Sex: } \\
\hline Male & 40 & 80 & 16 & $(45)$ & 24 & (55) & \multirow{2}{*}{$0.605 \ddagger$} \\
\hline Female & 10 & 20 & 4 & $(41.7)$ & 6 & $(58.3)$ & \\
\hline \multicolumn{8}{|l|}{ Pathological type: } \\
\hline Clear cell & 40 & 80 & 16 & $(40)$ & 24 & $(60)$ & \multirow{3}{*}{$0.397 \ddagger$} \\
\hline Papillary & 6 & 12 & 3 & $(50)$ & 3 & $(50)$ & \\
\hline Chromphobe & 4 & 8 & 1 & (20) & 3 & $(80)$ & \\
\hline \multicolumn{8}{|l|}{ Grade: } \\
\hline Grade I & 8 & 16 & 6 & (80) & 2 & $(20)$ & \multirow{4}{*}{$<0.001 \S$} \\
\hline Grade II & 18 & 36 & 10 & $(55)$ & 8 & $(45)$ & \\
\hline Grade III & 12 & 24 & 4 & $(35.3)$ & 8 & $(64.7)$ & \\
\hline Grade IV & 12 & 24 & 0 & $(0 \%)$ & 12 & $(100)$ & \\
\hline \multicolumn{8}{|l|}{ Size: } \\
\hline$<7 \mathrm{~cm}$ & 10 & 20 & 5 & (50) & 5 & $(50 \%)$ & \multirow{2}{*}{$0.307 \ddagger$} \\
\hline$>7 \mathrm{~cm}$ & 40 & 80 & 15 & $(44.2)$ & 25 & $(55.8)$ & \\
\hline$T:$ & & & & & & & \\
\hline $\mathrm{T} 1$ & 10 & 20 & 6 & (66.7) & 4 & (33.3) & \\
\hline $\mathrm{T} 2$ & 20 & 40 & 14 & (71.4) & 6 & $(28.6)$ & $<0.001 \S$ \\
\hline $\mathrm{T} 3$ & 10 & 20 & 1 & $(23.5)$ & 9 & (76.5) & \\
\hline $\mathrm{T} 4$ & 10 & 20 & 0 & $(0)$ & 10 & $(100)$ & \\
\hline$N:$ & & & & & & & \\
\hline N0 & 30 & 60 & 18 & (70.6) & 12 & $(29.4)$ & \\
\hline N1 & 20 & 40 & 2 & $(19.2)$ & 18 & $(80.8)$ & $0.008 \ddagger$ \\
\hline$M:$ & & & & & & & \\
\hline M0 & 40 & 80 & 19 & $(57.1)$ & 21 & $(42.9)$ & $004+$ \\
\hline M1 & 10 & 20 & 1 & $(9.1)$ & 9 & $(90.9)$ & $0.04+$ \\
\hline AJCC Stage group: & & & & & & & \\
\hline Stage I & 10 & 20 & 6 & $(50.1)$ & 4 & $(50.0)$ & $0.008 \S$ \\
\hline Stage II & 20 & 40 & 10 & $(50 \%)$ & 10 & $(50 \%)$ & \\
\hline Stage III & 10 & 20 & 4 & $(33.3)$ & 6 & $(66.7)$ & \\
\hline Stage IV & 10 & 20 & 0 & $(0 \%)$ & 10 & $(100)$ & \\
\hline$E Z H 2:$ & & & & & & & \\
\hline Negative & 22 & 40 & 17 & $(86.7)$ & 5 & $(13.3)$ & $<0001+$ \\
\hline Positive & 28 & 60 & 3 & (10) & 25 & $(90)$ & $0.001+$ \\
\hline Twist-1: & & & & & & & \\
\hline Low & 20 & 80 & & & & & \\
\hline High & 30 & 20 & & & & & \\
\hline
\end{tabular}

* Mann Whitney U test. $\ddagger$ Chi-square test. $\$$ Chi-square test for trend. 
Table (4): Correlations between clinicopathological features, expressions of both markers together in our patients.

\begin{tabular}{|c|c|c|c|c|c|c|c|c|c|c|c|}
\hline \multirow{2}{*}{ Characteristics } & \multicolumn{2}{|c|}{$\begin{array}{c}\text { All } \\
(\mathrm{N}=50)\end{array}$} & \multicolumn{2}{|c|}{$\begin{array}{c}\text { Low/Low } \\
(\mathrm{N}=20)\end{array}$} & \multicolumn{2}{|c|}{$\begin{array}{l}\text { Low/High } \\
\quad(\mathrm{N}=5)\end{array}$} & \multicolumn{2}{|c|}{$\begin{array}{l}\text { High/Low } \\
(\mathrm{N}=5)\end{array}$} & \multicolumn{2}{|c|}{$\begin{array}{l}\text { High/High } \\
(\mathrm{N}=20)\end{array}$} & \multirow{2}{*}{$p$-value } \\
\hline & No. & $(\%)$ & No. & $(\%)$ & No. & $(\%)$ & No. & $(\%)$ & No. & $(\%)$ & \\
\hline \multicolumn{12}{|l|}{ Age (years): } \\
\hline Mean \pm SD & \multirow{2}{*}{\multicolumn{2}{|c|}{$\begin{array}{c}59.65 \pm 10.12 \\
64(40-77)\end{array}$}} & \multirow{2}{*}{\multicolumn{2}{|c|}{$\begin{array}{l}57 \pm 10.38 \\
62(40-77)\end{array}$}} & \multirow{2}{*}{\multicolumn{2}{|c|}{$\begin{array}{c}57 \pm 9.53 \\
58(47-66)\end{array}$}} & \multirow{2}{*}{\multicolumn{2}{|c|}{$\begin{array}{l}62.80 \pm 7.32 \\
65(50-68)\end{array}$}} & \multirow{2}{*}{\multicolumn{2}{|c|}{$\begin{array}{c}61.81 \pm 10.18 \\
66(40-75)\end{array}$}} & $0.155^{*}$ \\
\hline Median (Range): & & & & & & & & & & & \\
\hline$\leq 55$ years & 20 & $(40)$ & 8 & $(50)$ & 2 & (8.3) & 1 & $(4.2)$ & 9 & $(37.5)$ & $0.409 \ddagger$ \\
\hline$>55$ years & 30 & (60) & 12 & $(36.1)$ & 1 & (2.8) & 4 & (11.1) & 13 & $(50)$ & \\
\hline \multicolumn{12}{|l|}{ Sex: } \\
\hline Male & 40 & $(80)$ & 17 & $(45.8)$ & 1 & $(2.1)$ & 1 & $(6.3)$ & 21 & $(45.8)$ & $0.095 \ddagger$ \\
\hline Female & 10 & (20) & 3 & $(25)$ & 1 & $(16.7)$ & 1 & $(16.7)$ & 5 & $(41.7)$ & \\
\hline \multicolumn{12}{|l|}{ Pathological type: } \\
\hline Clear cell & 40 & $(80)$ & 17 & $(41.3)$ & 3 & $(6.5)$ & 5 & $(10.9)$ & 15 & $(41.3)$ & $0.554 \ddagger$ \\
\hline Papillary & 6 & (12) & 2 & $(55.6)$ & 0 & (0) & 0 & (0) & 4 & (44.4) & \\
\hline Chromphobe & 4 & (8) & 1 & $(20)$ & 0 & (0) & 0 & $(0)$ & 3 & $(80)$ & \\
\hline \multicolumn{12}{|l|}{ Grade: } \\
\hline Grade I & 8 & (25) & 5 & $(80)$ & 1 & $(6.7)$ & 1 & $(6.7)$ & 1 & $(6.7)$ & $<0.001 \S$ \\
\hline Grade II & 18 & (36.7) & 8 & $(45.5)$ & 1 & $(4.5)$ & 1 & $(4.5)$ & 8 & $(45.5)$ & \\
\hline Grade III & 12 & $(28.3)$ & 2 & (17.6) & 0 & (0) & 2 & $(17.6)$ & 8 & (64.7) & \\
\hline Grade IV & 12 & (10) & 0 & (0) & 1 & (16.7) & 0 & (0) & 12 & $(83.3)$ & \\
\hline \multicolumn{12}{|l|}{ Size: } \\
\hline$<7 \mathrm{~cm}$ & 10 & (20) & 5 & $(52.9)$ & 0 & $(0)$ & 1 & $(11.8)$ & 4 & $(35.3)$ & $0.433 \ddagger$ \\
\hline$>7 \mathrm{~cm}$ & 40 & $(80)$ & 17 & $(45.8)$ & 1 & (2.1) & 1 & $(6.3)$ & 21 & (45.8) & \\
\hline \multicolumn{12}{|l|}{$T:$} \\
\hline $\mathrm{T} 1$ & 10 & (20) & 6 & $(60)$ & 0 & $(0)$ & 1 & $(13.3)$ & 3 & (26.7) & $0.001 \S$ \\
\hline $\mathrm{T} 2$ & 20 & (40) & 10 & (61.9) & 2 & (0) & 2 & $(9.5)$ & 6 & (28.6) & \\
\hline $\mathrm{T} 3$ & 10 & (20) & 2 & (17.6) & 2 & (17.6) & 1 & (5.9) & 5 & $(58.8)$ & \\
\hline $\mathrm{T} 4$ & 10 & (20) & 0 & (0) & 0 & (0) & 0 & (0) & 10 & $(100)$ & \\
\hline \multicolumn{12}{|l|}{$N:$} \\
\hline N0 & 30 & $(60)$ & 16 & $(61.8)$ & 0 & $(0)$ & 4 & (11.8) & 10 & $(26.5)$ & $<0.001$ 末 \\
\hline N1 & 20 & (40) & 4 & $(15.4)$ & 4 & $(11.5)$ & 2 & $(3.8)$ & 10 & $(69.2)$ & \\
\hline \multicolumn{12}{|l|}{$M:$} \\
\hline M0 & 40 & $(80)$ & 15 & $(45.8)$ & 1 & $(2.1)$ & 1 & $(6.3)$ & 13 & $(45.8)$ & $<0.001 \ddagger$ \\
\hline M1 & 10 & (20) & 1 & $(9.1)$ & 2 & $(18.2)$ & 0 & (0) & 7 & (72.7) & \\
\hline \multicolumn{12}{|l|}{ AJCC Stage group: } \\
\hline Stage I & 10 & (20) & 6 & $(60)$ & 0 & $(0)$ & 2 & $(13.3)$ & 2 & $(26.7)$ & $<0.001 \S$ \\
\hline Stage II & 20 & (40) & 12 & (63.2) & 0 & (0) & 3 & $(10.5)$ & 5 & (26.3) & \\
\hline Stage III & 10 & (20) & 2 & $(25)$ & 1 & $(8.3)$ & 0 & $(8.3)$ & 7 & $(58.3)$ & \\
\hline Stage IV & 10 & (20) & 1 & (7.1) & 2 & (14.3) & 0 & (0) & 7 & (78.6) & \\
\hline
\end{tabular}

* Mann Whitney U test. $\quad$ \$Chi-square test. $\quad \S$ Chi-square test for trend.

\section{Discussion}

In more than $65 \%$ of RCC cases of different histopathological features the disease is localized and curable at time of diagnosis but there are still about $30 \%$ of cases present with advanced disease or with L.Ns and distant metastases at the time of diagnosis, that could worsen the prognosis and leads to fatal outcome [11]. So studying and understanding the molecular pathogenesis of invasion, progression and metastases of RCC might help in identification of recent therapeutic targets for treatment and improving the prognosis of patients with such type of cancer. As cancer is now consid- ered a genetic disease, so it needs many genetic alteration and combinations of many genes for its initiation, promotion and progression. Recently the epigenetic alterations that include DNAmethylations, histone-modifications, and miroRNA changes, were considered cancer promoting factors [12]. The epigenetic alterations differed from the genetic changes in that; they could be reversed by their inhibitors, but that could not happen in the genetic changes or in DNA mutations. We choose the EZH-2 for evaluation as it was found to play a role of such epigenetic change in cancer. 
In our study, we found that high expression of EZH2 was significantly positively correlated with higher grade and stage of the tumor, presence of distant metastases and presence of L.N metastases. Our results were near to results of $\mathrm{Xu}$ et al., who proved that EZH 2 expression levels were positively related to poor clinicopathological and prognostic parameters, RCC progression, higher grade of RCC and advanced stage which points to role of EZH2 as a novel PCC prognostic marker [13]

Liu et al., proved that that increased EZH2 expression could be a predictive of RCC patients' overall and progression free survival rates that were in line with our results [14]. Our results and results of previous studies will add to the prognostic role of TNM-stage in RCC as such value will improve when it is combined with EZH2 levels of expression. Also EZH2 expression could be considered a clinically easily applicable method of differentiation of RCC patients with different outcomes. That will lead to individualized management of RCC patients. In line with our results; Wagener et al.,: Have proved that EZH2 could be considered a recent marker of dismal prognosis in RCC-patients [15].

Many other previous researchers have proved results similar to us that increased EZH2 expression was related to worse clincopathological features and dismal outcomes of patients having malignancies of organs other than the kidney [16,17]

Different from us were results of Stefan Hinz and colleagues who showed that increased levels of expression of EZH2 were related to less aggressive parameters and were related to favorable outcomes of RCC patients' if they are assessed by real-time PCR [18]

The different method of evaluation of EZH-2 expression levels between us and the other study is responsible for such conflicting results.

Our results were explained by Z. Q. Xu et al., who clarified that increased expression of EZH2 enhanced RCC progression by increasing angiogenesis that subsequently increased RCC size, invasion, L.N and distant metastases [13].

Additionally silencing of EZH2 gene suppresses malignant cells growth, leads to cell cycle arrest and stimulate apoptosis of cancer cells, while its overexpression promotes malignant cells growth and inhibited apoptosis in them. So EZH2 knocking down might inhibit malignant cells proliferation and increased apoptosis $[\mathbf{1 9 , 2 0 ]}$. All these results that are in line with us point to the benefit of using targets against EZH-2 in RCC therapy, as EZH2 inhibitors decreased malignant growth, invasion and metastases.

The process in which cells could change their phenotype from the epithelial to the mesenchymal states is called the epithelial-mesenchymal transition (EMT). EMT leads to many changes in the differentiated characteristics of the cells e.g. Adhesion and apical basal polarity between cells, additionally, leads to change in the absence of mobility and acquire instead mesenchymal characters e.g. invasiveness motility, and resistance to apoptosis and by such process malignant cells could acquire invasive and metastatic capability [5]. EMT is regulated by plethora of transcription factors like Twist-1.

In our study we have proved that increased Twist-1 expression was significantly positively correlated with higher grade and stage of the tumor, presence of distant metastases and presence of L.N metastases.

Results of our study were similar to results of Kojiro Ohba, et al., [21], that proved that Twist over expression was positively correlated with RCC higher grade, advanced pathological tumor stage stage, higher incidence of invasion and metastasis in RCC patients.

The meta-analysis that was done by Wushou et al., [22], proved similar to us that; immunohistochemical expression of Twist- 1 is related to poor prognosis in cancer patients that point to the development of therapeutic targets against such transcription factor is a useful therapeutic method.

Additionally Wright et al., [23], found results similar to ours that demonstrated the role of Twist1 in EMT induction in RCC cells.

Additionally, similar to our results Harada et al., [24], have found that increased Twist expression is associated with poor prognosis in RCC patients.

Previous researches regarding different types of cancer found nearly similar results to ours in RCC that Twist- 1 overexpression is related to poor clinicopathological and prognostic parameters in various cancer types $[\mathbf{2 5 , 2 6}]$, increased Twist- 1 expression is associated with poor patients prognosis, higher grade and advanced stage [22]. In squamous cell carcinoma of the oral cavity increased Twist-1 expression could predict L.Ns, lung and distant metastases occurrence and also related to poor patient survival. So near our results in RCC Twist-1 over-expression is considered a 
poor prognostic sign and was related to poor survival rates of cancer patients having different types of cancer [27-29]. Our results are clarified by the Twist- 1 played its pro-metastatic role by its ability to stimulate the EMT which is the process that transforms cells to more invasive and motile subtypes that is able to break through the basement membrane and invade the surrounding extracellular matrix [30].

Results of our research regarding Twist- 1 expression and its role in RCC progression may help to detect a new therapeutic target aiming for adequate management to decreases the invasiveness and metastases of RCC, that was in line with [31]

When we correlated the expression of EZH-2 and Twist- 1 expression together we demonstrate that there is a significant direct relation between both markers expressions in RCC and Combination of EZH-2 \& Twist overexpression was significantly positively correlated with grade, stage of the tumor, presence of L.Ns and D.M ( $p<0.001$ for all). Suggesting that a combination of EZH-2 \& Twist expression could predict disease outcome and it will be beneficial to use therapeutic inhibitors of both markers.

\section{Summary and Conclusions:}

In summary, we tried to correlate the tissue protein expression of EZH-2 and Twist-1 aiming to detect novel therapeutic targets our results and found that overexpression of both EZH-2 \& Twist1 expression is a marker of poor prognosis in patients with RCC.

The positive association between both markers proved that the combination of molecular inhibitors against both of them could be used for inhibition of occurrence of invasion and metastases in RCC. We recommend performing other studies on EZH$2 \&$ Twist- 1 expression in different types of cancer to prove their value on cancer molecular targeted therapy.

\section{Conflicts of interest:}

Authors declared no conflicts of interest.

\section{References}

1- SIEGEL R.L., MILLER K.D. and JEMAL A.: Cancer Statistics, CA. Cancer. J. Clin., 67: 7-30, 2017.

2- G.D. STEWART, F.C.O' MAHONY, T. POWLES, et al.: "What can molecular pathology contribute to the management of renal cell carcinoma?" Nature. Reviews. Urology, Vol. 8, No. 5, pp. 255-265, 2011.

3- FICARRA V., GALFANO A., MANCINI M., et al.: TNM staging system for renal-cell carcinoma: Current status and future perspectives. Lancet Oncol 8: 554-558. Doi: 10.1016/ S1470-2045(07)70173-0.PubMed: 17540307, 2007.

4- NIU X., ZHANG T., LIAO L., et al.: The von HippelLindau tumor suppressor protein regulates gene expression and tumor growth through histone demethylase JARID1C. Oncogene, 31: 776-786. doi:10.1038/onc.2011.266. PubMed: 21725364, 2012.

5- POLYAK K. and WEINBERG R.A.: Transitions between epithelial and mesenchymal states: Acquisition of malignant and stem cell traits. Nat. Rev. Cancer, 9: 265-273, 2009.

6- LI L.; CSERJESI P. and OLSON E.N. DERMO.: A novel twist-related bHLH protein expressed in the developing dermis. Dev. Biol., 172, 280-292, 1995.

7- AMIN M.P., GREENE F.L., EDGE G.S., et al.: The Eighth Edition AJCC Cancer Staging Manual: Contributing to build a bridge from a population to more personalized approach to cancer stage. CA Cancer. J. Clin., 67: 93-99, 2017.

8- INAMURA K.: Renal cell Tumors: Understanding their molecular pathological epidemiology and the 2016 WHO classification. Int. J. Mol. Sci., 18 (10): 2195-2210, 2017.

9- HSU S.M., RAINE L. and FANGER H.: Use of avidinbiotin-peroxidase complex $(\mathrm{ABC})$ in immunoperoxidase techniques: a comparison between $\mathrm{ABC}$ and unlabeled antibody (PAP) procedures. J. Histochem. Cytochem., 29: 577-580, 1981.

10- WEICHERT W., RÖSKE A., GEKELER V., et al.: Association of patterns of class I histone deacetylase expression with patient prognosis in gastric cancer: A retrospective analysis. Lancet Oncol 9: 139-148. Doi: 10.1016/S14702045(08)70004-4. PubMed: 18207460, 2008.

11- EISENGART L.J., MACVICAR G.R. and YANG X.J.: Predictors of response to targeted therapy in renal cel carcinoma. Archives of Pathology \& Laboratory Medicine, 136 (5): 490-5. doi: 10.5858/arpa.2010-0308-RA PMID: 22229848, 2012

12- MOSS T.J. and WALLRATH L.L.: Connections between epigenetic gene silencing and human disease. Mutat. Res., 618: 163-174. doi:10.1016/ j.mrfmmm.2006.05.038. PubMed: 17306846, 2007.

13-Z.Q. XU, L. ZHANG, B.S. GAO, et al.: EZH2 promotes tumor progression by increasing VEGF expression in clear cell renal cell carcinomaClin Transl Oncol 17:4149 DOI 10.1007/s12094-014-1195-5, 2015.

14- LIU L., XU Z., ZHONG L., et al.: Prognostic Value of EZH2 Expression and Activity in Renal Cell Carcinoma: A Prospective Study. PLoS ONE 8 (11): e81484. doi:10. 1371/journal.pone.0081484, 2013.

15- WAGENER N., MACHER-GOEPPINGER S., PRITSCH M., et al.: Enhancer of zeste homolog 2 (EZH2) expressions is an independent prognostic factor in renal cell carcinoma. BMC. Cancer., 10: 524, 2010.

16- XU K., WU Z.J., GRONER A.C., et al.: EZH2 oncogenic activity in castration-resistant prostate cancer cells is polycomb-independent. Science., 338: 1465-9, 2012.

17- JENE-SANZ A., VARALJAI R., VILKOVA A.V., et al.: Expression of polycomb targets predicts breast cancer prognosis. Mol. Cell. Biol., 33: 3951-61, 2013. 
18- HINZ S., WEIKERT S., MAGHELI A., et al.: Expression profile of the polycomb group protein enhancer of Zeste homologue 2 and its prognostic relevance in renal cell carcinoma. J. Urol., 182: 2920-2925. doi:10.1016/j .juro. 2009.08.014.PubMed: 19846140, 2009.

19-HUBAUX R., THU K.L., COE B.P., et al.: EZH2 promotes E2F-driven SCLC tumorigenesis through modulation of apoptosis and cell-cycle regulation. J. Thorac. Oncol., 8: 1102-6, 2013

20- NAKAGAWA S., OKABE H., SAKAMOTO Y., et al.: Enhancer of zeste homolog 2 (EZH2) promotes progression of cholangiocarcinoma cells by regulating cell cycle and apoptosis. Ann. Surg. Oncol., 20 (Suppl 3): S667-75, 2013.

21- KOJIRO OHBA, YASUYOSHI MIYATA, TOMOHIRO MATSUO, AKIHIRO ASAI, KENSUKE MITSUNARI, YOHEI SHIDA, SHIGERU KANDA and HIDEKI SAKAI: High expression of Twist is associated with tumor aggressiveness and poor prognosis in patients with renal cell carcinoma Int. J. Clin. Exp. Pathol., 7 (6): 3158-3165, 2014.

22- WUSHOU A., HOU J., ZHAO Y.J., et al.: Twist-1 upregulation in carcinoma correlates to poor survival. Int. J. Mol. Sci., 15:21621-30, 2014.

23- WRIGHT T.M., BRANNON A.R., GORDAN J.D., MIKELS A.J., MITCHELL C., CHEN S., ESPINOSA I., VAN DE RIJN M., PRUTHI R., WALLEN E., EDWARDS L., NUSSE R., RATHMELL W.K.: Ror2, a developmentally regulated kinase, promotes tumor growth potential in renal cell carcinoma. Oncogene., 28: 251323, 2009.

24- HARADA K., MIYAKE H, KUSUDA Y. and FUJISAWA M.: Expression of epithelial-mesenchymal transition markers in renal cell carcinoma: Impact on prognostic outcomes in patients undergoing radical nephrectomy. BJU. Int., 110: 1131-1137, 2012.

25- MALFETTONE A., SILVESTRIS N., PARADISO A.,
MATTIOLI E., SIMONE G. and MANGIA A.: Overexpression of nuclear NHERF1 in advanced colorectal cancer: Association with hypoxic microenvironment and tumor invasive phenotype. Exp. Mol. Pathol., 92: 296303, 2012.

26- CREIGHTON C.J., GIBBONS D.L. and KURIE J.M.: The role of epithelial-mesenchymal transition programming in invasion and metastasis: A clinical perspective. Cancer. Manag. Res., 5: 187-95, 2013.

27- ZENG J., PING ZHAN2*, GUANNAN W.U.2, WEN YANG2, WENJUN LIANG2, TANGFENG L.V.1,2 and YONG SONG1,2: Prognostic value of Twist in lung cancer: Systematic review and meta-analysis Transl. Lung. Cancer. Res., 4 (3): 236-241, 2015.

28- SUNG C.O., LEE K.W., HAN S., et al.: Twist1 is upregulated in gastric cancer-associated fibroblasts with poor clinical outcomes. Am. J. Pathol., 179: 1827-1838, 2011.

29- WALLERAND H., ROBERT G., PASTICIER G., RAVAUD A., BALLANGER P., REITER R.E. and FERRIÈRE J.M.: The epithelial-mesenchymal transition-inducing factor TWIST is an attractive target in advanced and/or metastatic bladder and prostate cancers. Urol. Oncol., Sep-Oct., 28 (5): 473-9, 2010. doi: 10.1016/ j.urolonc. 2008.12.018. Epub 2009 Mar 9.

30- NAKAYA Y. and SHENG G.: Epithelial to mesenchymal transition during gastrulation: an embryological view. Dev. Growth. Differ. Dec., 50 (9): 755-66. (REVIEW), 2008.

31- DA SILVA S.D., MOULAY A. ALAOUI-JAMALI, FERNANDO AUGUSTO SOARES, DIRCE MARIA CARRARO, HELENA PAULA BRENTANI, MICHAEL HIER, SILVIA REGINA ROGATTO and LUIZ PAULO KOWALSKI: Twist 1 is a Molecular Marker for a Poor Prognosis in Oral Cancer and Represents a Potential Therapeutic. Target., 120: 352-62. VC 2013 American Cancer Society, 2014

\section{الأهمية الإكلينيكية والباثولوجية لإظهار بروتين HDAC \& SPoCK1 في حالات سروطان المثانة}

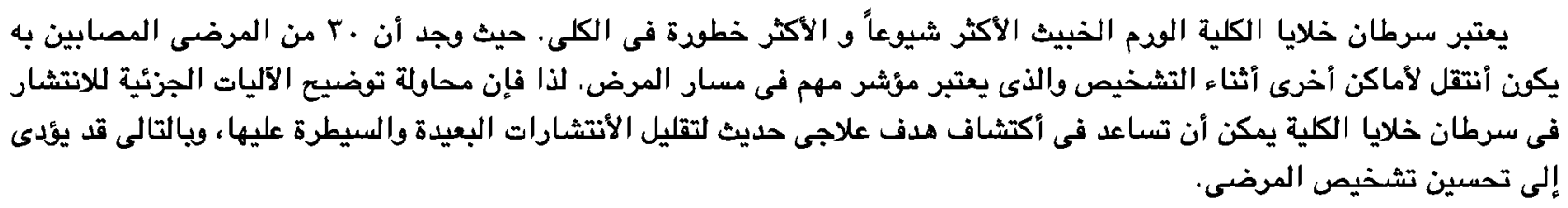

